\title{
THE ROLE OF CULTURAL DIFFERENCES IN CUSTOMER RETENTION: EVIDENCE FROM THE HIGH-CONTACT SERVICE INDUSTRY
}

\author{
Kim-Shyan Fam \\ Harbin University of Commerce \\ Boon Liat Cheng \\ Sunway University \\ Tat-Huei Cham iD \\ UCSI University \\ Mandy Tan Chia Yi \\ Sunway University \\ Hiram Ting iD \\ UCSI University
}

Polytechnic University of the Philippines

Current tourism landscape and dynamism of the business environment have increased market competitiveness in the high-contact service industry. Hotel operators must now pay greater heed to customer retention by exploring ways to improve customer engagement and experience. Toward this end, this study aimed to examine the interplays between relationship marketing, perceived service quality, corporate image, customer satisfaction, and customer loyalty, as well as the moderating effect of cultural difference between Asian and Western tourists. Using a questionnaire, data were collected from 400 international tourists and analyzed with the structural equation modeling technique. While the direct relationships pertaining the variables of interest were found to be significant, Asian tourists appeared to hold stricter standards in employee-customer interactions and satisfaction-based loyalty than Western tourists. Discussion and implications are provided to promote the development of fruitful hotelcustomer relationships in this industry with a heightened customer orientation.

KEYWORDS: relationship marketing; perceived service quality; corporate image; customer satisfaction; customer loyalty; cultural difference; hotel industry 


\section{INTRODUCTION}

The Association for Supply Chain Management (2020) defines high-contact service as a service environment that involves a high degree of interaction between customers and service providers, such as hotels, health care facilities, educational institutions, commercial transits, and retail enterprises that favor personalized customer service over operation-based service. In view of its frequent and diverse tourist encounters, the tourism industry undoubtedly falls into this category. The tourism sector encompasses multifaceted components, including transportation, accommodation, food and beverage, entertainment, and related operations (e.g., tour operators and tourism organizations; Open Access Publisher, 2020). As such, all-inclusive packages have gained popularity among hoteliers in recent years as they expand their offerings beyond mere accommodations. For instance, the Studio City in Macau is home to a wide variety of tourist-friendly facilities ranging from transportation services and restaurants to casinos, shopping complexes, and 4D rides. The assertion that tourism is a highcontact service industry is reinforced by its experiential assessment of tourist satisfaction through substitution costs, experience quality, disputes or complaints, and the extent to which tourism experiences shape lasting perceptions and lifestyles (Hospitality Net, 2020).

Tourism has gained substantial recognition on the global economic front, supporting 330 million in employment while constituting 10.3\% of international GDP (World Travel \& Tourism Council, n.d.). According to Lock (2020a), the travel and tourism industry channeled approximately USD2.9 trillion to international GDP in 2019, with the United States being the largest contributor. Reports show that France, Spain, the United States, China, and Italy were the five most visited destinations by international tourists in 2018 (U.N. World Tourism Organization, 2019). Although only one Asian country made the top five, the Asia-Pacific region is growing to be a lucrative tourist destination due to its geographical appeal and ideal scenery. In fact, the region accounted for USD339.5 billion of international inbound receipts in 2019 (World Economic Forum, 2020). Thus, while prior reports have named Western countries as top contenders in the industry, Asian countries are becoming increasingly competitive in the tourism sector.

Nevertheless, its growth does not negate the fact that the Asian tourism industry has faced serious challenges in recent years. Unable to achieve its yearly tourist arrival target for the previous 5 years, Malaysia's tourism receipts were forecasted to reduce to RM100 billion in 2020 (Ganesan, 2018). Such prediction was rather optimistic as it failed to foresee the international outbreak of COVID19 (coronavirus disease 2019). The U.N. World Tourism Organization (2020) reported that a total deficit of USD450 million is expected in the year following the pandemic (i.e., approximately one third of the industry's global revenue). With China leading the sector's downturn, Asia is deemed to be the greatest victim of the decline in tourism revenue (Lock, 2020b). This negative impact 
has been exacerbated by the World Health Organization's (WHO; 2020) "\#healthyathome" campaign for indoor sustainability, government controls, and social distancing orders imposed by multiple nations. Given these challenges facing the industry and the fact that attaining new customers costs five to 25 times more than retaining existing ones (Gallo, 2014), it is imperative to assess the factors that promote tourist retention (Milan et al., 2015).

The variations in tourists' nationalities fundamentally affect their perceptions toward specific traveling components (e.g., cultural display, adaptability, service fulfilment, price, and localized relationship-building). This has been demonstrated to influence tourists' destination selection (Jin et al., 2016) as well as explain tourists' travel purpose, satisfaction, segmentation, underlying intentions, and knowledge-seeking behavior (Soldatenko \& Backer, 2019). Besides nationality, the relevance of customers' cultural backgrounds in establishing their predispositions for specific offerings is also of interest (Cham, Cheng, \& Ng, 2020; Cham \& Easvaralingam, 2012). In fact, apparent disparities have been found between Western and Asian tourists in terms of satisfaction and retention (Weber et al., 2017). Specifically, Westerners' emphasis on utility and value-for-money is in contrast with Asians' focus on emotion and novelty (Williams et al., 2017). Cham and Easvaralingam (2012) have also discovered a greater expectation for service quality among Asian travelers compared with their Western counterparts. Overall, perception differences between cultures remain prevalent in today's tourism community.

Considering the industry's volatile nature, studies on hotels' relationship marketing have been useful in gauging the profitability of customer relationships (Harker, 1999). Substantial literature has thus explored the impacts of perceived service quality (Ali et al., 2017; Sukhragchaa \& Oh, 2018), relationship marketing (Panjaitan \& Laely, 2017), and corporate image (Cheng et al., 2017; Cheng \& Rashid, 2015) on customer satisfaction as well as customer loyalty (Meesala \& Paul, 2018). However, several gaps remain in this area of research. First, the study of relationship marketing has focused more on the banking and financial sector, whereas the travel and tourism sector has been relatively understudied. Second, while relationship marketing and perceived service quality have been widely examined as distinct independent constructs, little is known about the causal influence of the former on the latter. Third, the links between the aforementioned variables have often been investigated within a relational context, with limited examinations on potential boundary factors. Taking into account the roles of relationship marketing and cultural differences in the tourism industry, the current study aimed to investigate the moderating influence of cultural differences (i.e., Asian vs. Western cultures) on the interrelationships between relationship marketing, perceived service quality, corporate image, customer satisfaction, and customer loyalty. In view of the sector's current downturn, this study's results would provide valuable insights to tourism practitioners in recovering and progressing their businesses by strategically developing and maintaining strong customer relationships. 


\section{LITERATURE REVIEW}

\section{Customer Loyalty}

Based on previous reviews, Solnet and Kandampully (2008) emphasized a hotel's customer base as an asset of the highest value that is imperative for success. Customers act as brand ambassadors in an industry that lacks unique differentiating attributes and have far-reaching influence within the marketplace. Comparing loyal and nonloyal customers, Bowen and Chen (2001) had found that loyal customers tend to take a shorter time to decide on intended purchases as they are driven by preference instead of extended searches for better deals. This finding is in line with Skogland and Siguaw's (2004) proposition that customer loyalty signifies faithfulness toward a service or product. Following the above discussion, this study chose customer loyalty as the outcome of interest in view of its implications pertaining price insensitivity. Specifically, loyal tourists have an increased willingness to spend more or change dates for their intended travel due to their preference for a favored hospitality service provider or accommodation.

Although the title of this article carries the term customer retention, loyalty was tested as the dependent variable of its framework. Singh and Khan (2012) referred to loyalty as the disposition of a particular customer to acquire an organization's tangible and intangible offerings against its competitors. On the other hand, retention constitutes the emotional aspects induced through actual experience and corporate image; the connections forged by these emotions then support loyalty (Magatef \& Tomalieh, 2015). Keiningham et al. (2007) concurred that retention can occur through mere recommendations from acquaintances but is insufficient to cultivate loyalty on its own. Comprehensive definitions thus describe loyalty as relationship development and retention as relationship continuation. By outdoing competitors in term of products, pricing, and delivery, an organization can cultivate customer loyalty by creating positive customer experiences which lead to repeat purchases (Cheng, Gan, et al., 2019; X. J. Lim et al., 2018; Y. M. Lim et al., 2019; Magatef \& Tomalieh, 2015). Moreover, as the main element of customer retention, recurring clientele to an organization is closely related to relationship marketing (Hennig-Thurau \& Hansen, 2013).

Overall, retention is viewed as the process of achieving long-term loyalty. In this study on how relationship marketing, service quality, and corporate image promote customer satisfaction and ultimately loyalty in the high-contact service industry, the term customer retention therefore represents the proposed framework in its entirety.

\section{Relationship Marketing}

Relationship marketing was defined by Beetles and Harris (2010) as a marketing paradigm that emphasizes the development and retention of long-lasting customer relationships. It is further regarded by $\mathrm{Wu}$ and $\mathrm{Lu}$ (2012) as a 
continuous process aimed to transfer long-term value to customers. Palmatier (2008) then proposed that sustainable customer relationships are an influencing factor of service firms' long-term profitability. As reciprocity is necessary for organizations and customers to maintain a relationship, the success of such a relationship is dependent on both parties' engagement (W. G. Kim \& Cha, 2002). It should be noted that customers' perceptions are determined through their actual experience of a particular service; relationship marketing therefore calls for hotel operators to personalize their services to enhance customer experiences (Narteh et al., 2013). In this manner, relationship marketing transcends the marketing mix's short-term transactional gains by adopting a customer-oriented approach that offers personalized experiences and greater accessibility to achieve continued engagement and retention (W. G. Kim \& Cha, 2002).

Relationship marketing is an irreplaceable asset in today's digital environment, as it engenders loyalty from customers of diverse national and societal backgrounds and motivates destination-based buzz through well-targeted information across integrated channels (Arminda \& Sergio, 2017). Accordingly, positive relationships have been exhibited between trust and customer loyalty, social responsibility and relationship engagement, as well as specialized treatment and customer appreciation (Chou \& Chen, 2018). While customer loyalty holds a dominant role in developing lasting buyer-seller relationships in service organizations, differences prevail between high-contact and moderate- or lowcontact services, whereby in the latter, social responsibilities and personalized treatment are deemed secondary to patronage (Srihadi \& Setiawan, 2015). Kinard and Capella (2006) further highlighted the greater benefits of customer loyalty in high-contact organizations with customizable services and encouraged programs capitalizing on customer involvement in these firms. This, however, was rebutted by E. L.-Y. Li et al. (2017), who found that the indirect relationship between customer trust and loyalty towards a service provider is more apparent in low-contact services.

Regardless of service type, every employee-customer interaction has substantial potential to affect customer satisfaction (Hennig-Thurau \& Hansen, 2013). As demonstrated by Berezan et al. (2017), relationship-building programs that increase information exchange and customers' knowledge directly enhance customers' positive feelings toward service providers, which indirectly boost customer satisfaction. Additionally, the study by Al-Nazer (2010) has shown that relationship marketing directly affects customer loyalty by stimulating customers' connectedness, confidence, networking, satisfaction, and engagement. As such, the importance of relationship marketing is evident in its impact on a satisfactory customer experience and customer loyalty.

Recent studies on the effect of relationship marketing on customer satisfaction (e.g., Panjaitan \& Laely, 2017) and customer loyalty (e.g., Dedeoğlu et al., 2015) have mainly explored the financial and banking sector, in view of its speculative nature and its management of customers' private information. Although today's marketing environment has advanced in many ways, relationship 
marketing continues to be a critical part of current and future marketing efforts in various business sectors (Berezan et al., 2017). Therefore, given the inconsistent findings on customer loyalty across service firms' contact levels and a lack of exploratory research in the tourism sector, the current study aspired to investigate relationship marketing as an independent variable affecting various customer-related outcomes in the tourism industry.

\section{Perceived Service Quality}

Perceived service quality represents a customer's overall assessment or impression of the relative inferiority or superiority of a specific service (Parasuraman et al., 1988). As outlined by Tsoukatos and Rand (2006), one's service evaluation is commonly dependent on elements of the service's delivery process, production, and outcome. Service quality is perceived as superior when customers' quality expectation is fulfilled, which can be detrimental if customers hold unrealistically high expectations despite excellent service (Grönroos, 1988). In other words, perceived service quality reflects the comparison of customers' actual service experience to their prior expectations (Parasuraman et al, 1988). Due to close mutual interactions, employees' service performance carries a significant impact on the fulfilment of customer expectations; likewise, customers' involvement in a service affects their perceptions of the service's quality (Tsoukatos \& Rand, 2006).

Perceived service quality has been commonly researched in terms of its direct and indirect influence on customer satisfaction (e.g., Miranda et al., 2018) and customer loyalty (e.g., Marković \& Janković, 2013). Dedeoğlu et al. (2015) stated that perceived service quality affects repurchase intention (i.e., loyalty) through the development of value perception. Additionally, a study by $\mathrm{Hu}$ et al. (2009) suggested a positive association between service quality and image, which ultimately influences customer satisfaction. In the context of high-contact services, studies in the banking and hotel sectors have demonstrated customers' perception of service quality as a significant predictive factor of positive customer outcomes (Ali et al., 2017). Perceived quality established through customer experience is indeed shown to influence the corporate image of hotels and resorts (W. J. Chen \& Chen, 2014). Therefore, enhanced perceptions of service quality via effective relationship marketing would directly promote customer retention and loyalty (Cham et al., 2016; Ryu \& Lee, 2017).

From another perspective, Holmlund and Kock (2006) proposed a favorable service experience as an essential precondition of a constructive business relationship. Customers' service perceptions act as the foundation of their trust and pleasure, which in turn encourage purchasing behaviors (Ryu \& Lee, 2017). A direct association between perceived service quality and customer-organization relationship quality was also proposed by $\mathrm{Su}$ et al. (2016) within the context of tourism. Moreover, both service quality and relationship quality emerged as independent variables that connect service characteristics to revisits (Sadeghi 
et al., 2017). Notably, relationship marketing is shown to precede relationship quality and ensure positive word-of-mouth (Bennett \& Barkensjo, 2005). However, recent studies have mainly appraised the influence of service quality on relationship-building, while neglecting the direct influence of relationship marketing on perceived service quality. Hence, direction of the causal influence between both variables remains ambiguous. Based on the above discussion, the current study proposed an inverse relationship in the high-contact tourism industry. The following hypotheses were thus postulated:

Hypothesis $\mathbf{1}_{\mathbf{0}}$ : Relationship marketing does not possess a positive influence on customers' perceived service quality within the high-contact service industry.

Hypothesis $\mathbf{1}_{\mathrm{a}}$ : Relationship marketing possesses a positive influence on customers' perceived service quality within the high-contact service industry.

\section{Corporate Image}

According to Christou (2003), corporate image signifies an organization's behavioral, psychological, and physical components, constituting elements such as services offered and perceptions of service providers. In the literature on service quality, corporate image is interchangeably termed corporate reputation (Chun, 2005). Within the context of tourism, a hotel's image is ultimately formed through customers' experiences; thus, it is crucial to identify the antecedents of hotels' corporate image and their influence on other constructs (Dedeoğlu et al., 2015). For example, hotels and resorts in Thailand attract new customers and promote long-term relationships by creating a favorable corporate image using relationship marketing.

The intangible nature of services demands greater emphasis on creating a superior corporate image, as a positive image in combination with effective marketing entails more benefits than just marketing efforts for service firms (Onkvisit \& Shaw, 1989). This may be challenging as the intangibility of services poses difficulties in evaluating the relationship of image with perceived service quality (Wilkins et al., 2009). Nevertheless, in the area of service improvement, corporate image has surfaced as an advanced basis for firms to map the effectiveness of public apologies and conflict resolutions in improving their service as well as to measure poststrategy customer satisfaction (Mostafa, 2017). Essentially, corporate image plays an intermediary role between organizational efforts and customers' perceptions.

On one end of the spectrum, corporate image is viewed as an outcome of organizational capabilities in the areas of service quality and relationship marketing (W. J. Chen \& Chen, 2014; Hu et al., 2009). Consistent with this view, W. J. Chen and Chen (2014) discovered the significant influence of relationship marketing and perceived service quality on hotels' corporate image, where service experiences provide the foundations for customers' perceptions. Likewise, relationship marketing, being an important determinant of customers' trust and 
satisfaction, has proven beneficial in forming a favorable organizational image (Christian et al., 2017). An integrated model was also proposed by C. K. Li and Hung (2009), which posited marketing tactics as direct antecedents of firm image and firm image as a predictor of customer loyalty. Despite numerous studies placing relationship marketing, service quality, and image as independent factors affecting the service landscape (Anggraini et al., 2016; Christian et al., 2017), the general consensus has been that a positive corporate image is a potential outcome of service providers' relationship marketing behaviors geared toward meeting customer expectations.

At the other end of the spectrum, corporate image has been found to positively influence customer loyalty (Cham \& Easvaralingam, 2012). This is supported by Wang and $\mathrm{Wu}$ (2012), who revealed corporate image as a direct antecedent to customer loyalty, though the strength of the association relies on customers' switching costs. Similarly, findings by Cheng and Rashid (2015) have indicated that corporate image is a direct predictor of customer satisfaction and loyalty. Cham and Easvaralingam (2012) further established that service quality has a stronger effect on customer loyalty than corporate image, though both are significant. Apart from direct effects, Engriani et al. (2019) proposed that organizational image, service quality, and perceived value indirectly influence loyalty and actual purchase intention through experience-based satisfaction. Kandampully et al. (2011) supported the indirect relationship between image and loyalty by way of excellent service. Based on these findings, the influence of image on loyalty appears to be dictated by various underlying mechanisms.

Undeniably, customers tend to favor firms with positive corporate images (Kandampully et al., 2011; X. J. Lim et al., 2020). Azhar et al. (2018) explored the indirect effects of organizations' service quality, environmental layout, customer-oriented conflict resolutions, network communications, and trust on customer satisfaction through the mediation of corporate image. In contrast, the current study acknowledged the significance of image as an intermediary by investigating it as a possible outcome of service quality and relationship marketing, as well as a potential predictor of customer loyalty. In the context of the high-contact industry, the following hypotheses were proposed:

Hypothesis $\mathbf{2}_{\mathbf{0}}$ : Relationship marketing does not possess a positive influence on corporate image of operators within the high-contact service industry.

Hypothesis 2 $\mathbf{a}_{\mathrm{a}}$ : Relationship marketing possesses a positive influence on corporate image of operators within the high-contact service industry.

Hypothesis $\mathbf{3}_{0}$ : Perceived service quality does not possess a positive influence on corporate image of operators within the high-contact service industry.

Hypothesis $\mathbf{3}_{\mathrm{a}}$ : Perceived service quality possesses a positive influence on corporate image of operators within the high-contact service industry.

Hypothesis $\mathbf{4}_{\mathbf{0}}$ : Corporate image does not possess a positive influence on customer loyalty within the high-contact service industry. 
Hypothesis $\mathbf{4}_{\mathrm{a}}$ : Corporate image possesses a positive influence on customer loyalty within the high-contact service industry.

\section{Customer Satisfaction}

Cadotte et al. (1987) explained that customer satisfaction is based on the expectancy-disconfirmation theory, which puts forth that customers form feelings of dissatisfaction or satisfaction after experiencing a service. This concept was further expanded by Smith et al. (1999) to include three dimensions of service evaluations, that is, perceived justice, procedural justice, and interactional justice. These dimensions link expectations to disconfirmation of service quality in situations of poor service. Harris and Goode (2004) subsequently asserted the importance of evaluating satisfaction as an overall perception rather than a transaction-specific event due to its impact on businesses.

In the service industry, satisfaction has often been shown to be a direct result of service quality (Jiang \& Zhang, 2016; Lacap et al., 2021; Meesala \& Paul, 2018). Service practitioners have thus made radical attempts to improve service quality to stimulate higher customer satisfaction (Marković \& Janković, 2013). According to Kasiri et al. (2017), (1) service quality can be enhanced through both service uniformity and personalization, (2) uniformity possesses a greater influence on service quality compared with personalization, (3) a service's practical characteristics have stronger impacts on satisfaction than service mechanisms, and (4) satisfaction derives long-term customer loyalty. Thus, while service quality might not directly predict loyalty, satisfaction may be an effective bridge linking these constructs (Jiang \& Zhang, 2016). Nonetheless, contextual differences have emerged between service industries (e.g., hospitals and hotels), as the attributes that lead to customer satisfaction vary across these industries (Cham, Cheng, Low, \& Cheok, 2020; Meesala \& Paul, 2018).

Rahimi and Kozak (2015) claimed that management efforts in strengthening customer relationships enhance customer satisfaction and experience. Studies in the hotel sector further verify relationship marketing activities as an important factor in guest satisfaction and customer relationship continuity, among other benefits (Gunjan, 2018; W. G. Kim \& Cha, 2002). In reference to customer loyalty, relationship marketing has a direct influence on satisfaction (Martínez \& Bosque, 2013), which subsequently motivates loyalty. Indeed, past studies have consistently reported that customer loyalty is formed based on customer satisfaction (e.g., Cheng, Cham, et al., 2019; Martínez \& Bosque, 2013). However, Leveren and Liljander (2006) suggested otherwise, finding that service-based relationships do not improve customer loyalty regardless of their transactional level, and that customer satisfaction achieved through enriched relationships is not necessary to retain profitable customers. Rather, relationship quality is implied as a mediating variable between effective relationship marketing and customer satisfaction (Santouridis \& Veraki, 2017). 
In meeting customers' expectations, transactional value and product offerings remain crucial contributors to tourists' satisfaction (Rahimi \& Kozak, 2015). Drawing from the expectancy-disconfirmation theory, service providers' efforts toward meeting and surpassing customer expectations would yield customer satisfaction, which in turn has a long-term impact on customer loyalty in the highcontact service industry. Therefore, the following hypotheses were developed:

Hypothesis 5: Relationship marketing does not possess a positive influence on customer satisfaction within the high-contact service industry.

Hypothesis $\mathbf{5}_{\mathrm{a}}$ : Relationship marketing possesses a positive influence on customer satisfaction within the high-contact service industry.

Hypothesis $6_{0}$ : Perceived service quality does not possess a positive influence on customer satisfaction within the high-contact service industry.

Hypothesis 6 $6_{\mathbf{a}}$ : Perceived service quality possesses a positive influence on customer satisfaction within the high-contact service industry.

Hypothesis $7_{0}$ : Customer satisfaction does not possess a positive influence on customer loyalty within the high-contact service industry.

Hypothesis $7_{\mathrm{a}}$ : Customer satisfaction possesses a positive influence on customer loyalty within the high-contact service industry.

\section{The Moderating Effect of Cultural Differences}

Customers' cultural upbringing, as proposed by Reisinger and Turner (1998), plays an essential role in determining their perceptions of service providers, as culture affects social interaction and individual satisfaction. Academic endeavors on culture in the hospitality industry have prioritized modernized societies such as Western and Asian communities (M. Li, 2014). For instance, Paris et al. (2014) noted differences in values upheld by Asian and Western tourists, though they share some common values. Cultural foundations thus affect tourists' perceptions at the individual level, especially their perception of personnel and service quality (Cham et al., 2021; Deng et al., 2019).

It has been reported that cultural background and geographical location drive travel patterns and destination planning (Paris et al., 2014). The consonance between both factors is hence critical in understanding the influence of an individual's culture on his or her destination image and consequent visit decision (Murphy et al., 2007). Loyalty to a tourist destination is thus attainable, though Western tourists display greater individual-destination congruency than Asian tourists (W. Kim \& Malek, 2016). This echoes the findings of Choi and Chu (2000) that transactional benefits outrank accommodation quality among Asian tourists, but not among their Western counterparts. However, contradictory evidence was presented by Williams et al. (2017), who found that Asians are more emotionally oriented, while Westerners are more economically oriented.

Additionally, Reisinger and Turner (2002) suggested that Asian tourists' perceptions go beyond service qualities to include cultural aspects, social 
interactions, and relationships. Seo (2012) then revealed that in their hotel experience, Western tourists prefer service-centric elements (i.e., service compatibility, reliability, customizability, and punctuality), whereas Asian tourists prefer elements of association and connection (i.e., staff politeness, communication, attentiveness). Therefore, cultural background has undeniable diverging effects on individuals' motivation to visit specific destinations (Jin et al., 2016). Based on this discussion, the following hypotheses were developed:

Hypothesis $\mathbf{8}_{\mathbf{0}}$ : Cultural differences between customers of Asian and Western origins do not moderate the relationship between relationship marketing and perceived service quality within the high-contact service industry.

Hypothesis $8_{\mathrm{a}}$ : Cultural differences between customers of Asian and Western origins moderate the relationship between relationship marketing and perceived service quality within the high-contact service industry.

Hypothesis 90: Cultural differences between customers of Asian and Western origins do not moderate the relationship between relationship marketing and corporate image of operators within the high-contact service industry.

Hypothesis 9: Cultural differences between customers of Asian and Western origins moderate the relationship between relationship marketing and corporate image of operators within the high-contact service industry.

Hypothesis $\mathbf{1 0}_{0}$ : Cultural differences between customers of Asian and Western origins do not moderate the relationship between perceived service quality and corporate image of operators within the high-contact service industry.

Hypothesis $10_{\mathrm{a}}$ : Cultural differences between customers of Asian and Western origins moderate the relationship between perceived service quality and corporate image of operators within the high-contact service industry.

Hypothesis 11 0 : Cultural differences between customers of Asian and Western origins do not moderate the relationship between corporate image and customer loyalty within the high-contact service industry.

Hypothesis 11 1 : Cultural differences between customers of Asian and Western origins moderate the relationship between corporate image and customer loyalty within the high-contact service industry.

Hypothesis 12 ${ }_{0}$ : Cultural differences between customers of Asian and Western origins do not moderate the relationship between relationship marketing and customer satisfaction within the high-contact service industry.

Hypothesis 12 : Cultural differences between customers of Asian and Western origins moderate the relationship between relationship marketing and customer satisfaction within the high-contact service industry.

Hypothesis 13 $_{0}$ : Cultural differences between customers of Asian and Western origins do not moderate the relationship between perceived service quality and customer satisfaction within the high-contact service industry.

Hypothesis 13 : Cultural differences between customers of Asian and Western origins moderate the relationship between perceived service quality and customer satisfaction within the high-contact service industry. 
Figure 1

Research Model

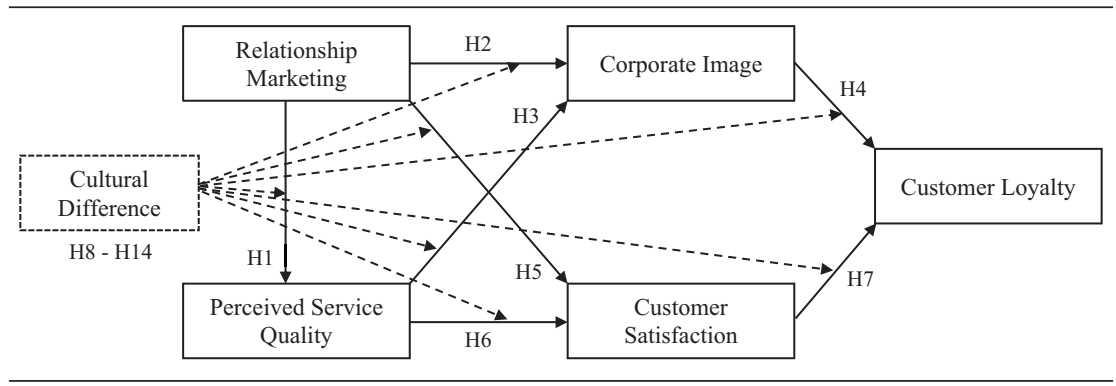

Hypothesis 14 $_{0}$ : Cultural differences between customers of Asian and Western origins do not moderate the relationship between customer satisfaction and customer loyalty within the high-contact service industry.

Hypothesis 14 a $_{\mathrm{a}}$ Cultural differences between customers of Asian and Western origins moderate the relationship between customer satisfaction and customer loyalty within the high-contact service industry.

Based on the thorough discussions presented in the earlier sections, the research model tested in the current study is presented in Figure 1.

\section{RESEARCH METHODOLOGY}

\section{Measurements and Questionnaire Development}

A paper-based questionnaire was used to assess the hypotheses of this study. The measurement instruments employed to operationalize the constructs were adapted from the existing literature as suggested by Luarn and Lin (2005), as the scales' validity has already been established. Although relationship marketing is a multidimensional concept contingent on customers' desires, it was treated as an independent construct in this study based on the extant literature. Indeed, scholars have investigated this variable among multiple accommodation service providers in the Asia-Pacific region, further highlighting the possibility of deviated findings among different cultural backgrounds. Additionally, relationship marketing, as a unidimensional construct, was examined in various later studies on relationship management in the hospitality sector (e.g., Chan et al., 2018; Sota et al., 2020). Since this study targeted the hotel industry, relationship marketing was measured using a 13-item scale by W. G. Kim et al. (2001), which assesses a hotel's overall effort in maintaining a relationship with their customers through their marketing activities. The instrument had been proven reliable in this context, thus solidifying relationship marketing as a viable construct. 
Perceived service quality was measured on a five-item scale adapted from Cham et al. (2021), Cheng et al. (2014), Hapsari et al. (2017), and Suhartanto (2011) in the high-contact service industry context. It was operationalized into the dimensions of assurance, responsiveness, reliability, tangibility, and empathy of the service experience. Next, corporate image was measured with a threeitem scale developed by Ladhari et al. (2011) to gauge guests' overall impression and perceived image of their respective hotels. For customer satisfaction, the four-item scale proposed by Olorunniwo et al. (2006) was adapted for this study to measure hotel guests' satisfaction based on their affective responses toward their service experience. Finally, customer loyalty was measured using a sevenitem scale adapted from Skogland and Siguaw (2004), which appraises the likelihood of hotel guests' repeated purchase, patronage to the hotel, and positive recommendations to close acquaintances (e.g., friends and family members). All the measurement items used in this study are presented in the online Supplemental Appendix.

All items were rated on a 6-point Likert-type scale ranging from $6=$ Strongly Agree to $1=$ Strongly Disagree. The decision to use a 6-point Likert-type scale is supported by the works of Infosurv (2006), Johns (2010), and Kulas et al. (2008). These scholars posit that the midpoint on an odd number scale (e.g., "3" on a 5-point scale) is commonly used by respondents to avoid sensitive questions and to provide socially desirable answers. This suggests that the midpoint is a "dumping ground" though respondents possess clear answers to questions, which distorts the impartiality of collected data. Infosurv (2006) thus proposed that a research sample must include individuals with real opinions or experiences pertaining to the investigated issue to reflect the rarity of a neutral response in their answers. Given the high-credence nature of hotel selection, guests are expected to be able to fully express their views on their experienced service. This study, therefore, adopted a 6-point Likert-type scale to assess respondents' perceptions, which is consistent with the recent tourism studies by AndradesCaldito et al. (2014), Cham et al. (2021), and G. Chen et al. (2020).

The developed questionnaire was pretested with 15 experts from the industry and academia and subsequently pilot-tested among 60 hotel guests prior to actual data collection. The preliminary responses obtained from both tests evinced that the questionnaire was well designed with no ambiguities. Face validity was thus established.

\section{Procedure and Sample}

To test the proposed hypotheses, customers' perceptions toward the hotel industry were determined as the most relevant context to exemplify the nature of high-contact services. Apart from tourism being fairly customer- $/$ tourist-centered, multiple previous studies on high-contact services have focused on appraising hospitality dimensions such as service development (Ottenbacher et al., 2006), service quality (Briggs et al., 2007), and critical 
service components (Stefano et al., 2015). Based on the rationale that satisfaction arises from performance that is equal to or higher than expectations, hotels involve in-depth engagement between employees and customers to ensure personalized solutions to customers' various requests without forgoing hotels' consistent standards in and above accommodations (i.e., timely transportation, suitable meals, customizable amenities, and resourceful entertainment). This justifies the hotel industry as a high-contact service industry, as corroborated by the Association for Supply Chain Management (2020). As such, it is pertinent to explore hotel services in this study on highcontact services.

The target respondents of this study were international tourists who, at the time of data collection, were visiting Malaysia for a vacation and had engaged hotel services during their stay. Data were collected at the Kuala Lumpur International Airport and the Kota Kinabalu International Airport in Malaysia. These airports were selected as they are the busiest airports in Malaysia with a significant volume of passengers (Joseph, 2018). Both quota and purposive sampling approaches were used to select 400 international tourists. Quota sampling was undertaken by evenly dividing the 400 respondents between both research locations. Meanwhile, purposive sampling was used to identify appropriate respondents who fulfilled two key criteria: (1) must be an international tourist and (2) must have stayed at least one night at a hotel in Malaysia during the visit. The questionnaires were personally distributed to tourists who fulfilled these requirements. According to Malhotra (2004), the researcher-administered survey prevails as the most effective method to create a cooperative atmosphere among respondents, which improves response rates and reduces uncertainties.

On an average, it took 15 minutes for the respondents to complete the questionnaire. Out of the 400 distributed questionnaires, 391 were usable while nine were rejected due to incompleteness and suspicious response patterns (e.g., alternating extreme pole responses, diagonal lining, and straight-lining). As for sample size, Saunders et al. (2012) argued that a sample size of 300 is sufficient to represent a large population, while a sample size of 200 is needed for structural equation modeling (SEM) analysis (Hair et al. 2010). The use of the G*Power software also shows that the sample size of 391 exceeded the minimum sample size of 129 based on an effect size of 0.15 at a $95 \%$ power level (Faul et al., 2009). Hence, the final sample size of 391 in the present study was sufficient (Memon et al., 2020). The collected data were analyzed using the Statistical Package for the Social Sciences Version 25 and the Analysis of Moment Structures Version 24.

Table 1 reports the demographic profile of the study respondents. In terms of gender, the respondents were almost equally distributed between females $(52.6 \%)$ and males (47.4\%). A majority of the respondents were married (77\%) and aged 25 years and younger $(28.3 \%)$. The top four tourist nationalities were Singapore (13.6\%), Indonesia (11.3\%), the United Kingdom (10.7\%), and China $(9.7 \%)$. Most respondents had visited the researched country between one and 
Table 1

Respondents' Demographic Profile

\begin{tabular}{|c|c|}
\hline Variable & Percentage \\
\hline \multicolumn{2}{|l|}{ Gender } \\
\hline Female & 52.6 \\
\hline Male & 47.4 \\
\hline \multicolumn{2}{|l|}{ Age (years) } \\
\hline 25 and younger & 28.3 \\
\hline $26-35$ & 28.1 \\
\hline $36-45$ & 25.3 \\
\hline $46-55$ & 15.8 \\
\hline $56-65$ & 2.0 \\
\hline 65 and older & 0.5 \\
\hline \multicolumn{2}{|l|}{ Marital status } \\
\hline Married & 77.0 \\
\hline Single & 18.4 \\
\hline Divorced & 2.3 \\
\hline Widowed & 2.0 \\
\hline Others & 0.3 \\
\hline \multicolumn{2}{|l|}{ Nationality } \\
\hline Singapore & 13.6 \\
\hline Indonesia & 11.3 \\
\hline United Kingdom & 10.7 \\
\hline China & 9.7 \\
\hline United States & 9.5 \\
\hline Australia & 5.9 \\
\hline France & 5.4 \\
\hline Thailand & 5.1 \\
\hline Germany & 4.3 \\
\hline Brunei & 3.3 \\
\hline Canada & 3.1 \\
\hline Netherlands & 2.8 \\
\hline India & 2.6 \\
\hline Saudi Arabia & 2.0 \\
\hline Italy & 2.0 \\
\hline Korea & 1.3 \\
\hline Denmark & 1.3 \\
\hline Pakistan & 1.0 \\
\hline Sweden & 1.0 \\
\hline Philippines & 0.8 \\
\hline New Zealand & 0.8 \\
\hline Japan & 0.5 \\
\hline Kazakhstan & 0.5 \\
\hline Qatar & 0.5 \\
\hline Spain & 0.5 \\
\hline
\end{tabular}


Table 1. (continued)

\begin{tabular}{lr}
\hline Variable & Percentage \\
\hline Gender & \\
Iran & 0.3 \\
Russia & 0.3 \\
Number of visit(s) to Malaysia & \\
1-3 times & 87.8 \\
$4-6$ times & 9.2 \\
$7-9$ times & 2.6 \\
More than 10 times & 0.5 \\
Cultural background & \\
Asians & 50.6 \\
Westerners & 49.4 \\
\hline
\end{tabular}

three times (87.8\%). In terms of cultural background, about half $(50.6 \%)$ the respondents were Asians, while the remaining half were Westerners.

\section{DATA ANALYSIS}

\section{Measurement Model Assessment}

Confirmatory factor analysis (CFA) was employed to test the validity of the measurement items for all the variables. The CFA examined the fit of the measurement model and validated both convergent and discriminant validity of the study constructs. As per Hair et al. (2010), the model fit was determined based on various indices. The common indices used to assess model fit are normed chi-square $\left(\chi^{2} / d f\right)$, root mean square error of approximation (RMSEA), goodness of fit (GFI), Tucker-Lewis index (TLI), and parsimony normed fit index (PNFI). Hair et al. (2010) recommended that a model be considered fit if $\chi^{2} / d f$ is less than 3, RMSEA is less than .08, GFI is greater than .90, TLI is greater than .90 , and PNFI is greater than .50. The results of this study's measurement model assessment showed that $\chi^{2} / d f$ was 2.162 , RMSEA was .055, GFI was .873, TLI was .920, and PNFI was .790. Therefore, the measurement model was deemed reasonably fit.

Convergent validity was assessed based on Hair et al.'s (2010) guideline, which states that convergent validity is established if the loadings for each construct item exceeds 0.60 , the value of each construct's average variance extracted $(A V E)$ is greater than 0.50 , and the composite reliability for each construct is equal to or greater than 0.70 . Initial assessment of the measurement model resulted in two items under relationship marketing being removed from further analyses due to loadings less than the recommended threshold value of 0.60 . After the removal of said items, the results in the online Supplemental Table 1 show that the measurement model satisfied the requirements of convergent 
validity. Specifically, factor loadings for all the items ranged from 0.626 to 0.887 , the $A V E$ value for all constructs were greater than the threshold value of 0.50 , and the composite reliability for all constructs were more than 0.70 .

Discriminant validity was evaluated based on the criterion by Fornell and Larcker (1981). It was determined based on two criteria: (1) comparison of the square roots of $A V E$ with the variance of the constructs and (2) comparison of $A V E$ values with the maximum shared variance $(M S V)$ of the constructs. According to Fornell and Larcker (1981), discriminant validity is achieved if the values of the variance shared between any two constructs are smaller than the values of the square roots of $A V E$, and $A V E$ values for all constructs are greater than the values of their respective $M S V \mathrm{~s}$. As depicted in the online Supplemental Table 2, all the square roots of $A V E$ (diagonal entries in bold) were greater than the correlation values (off-diagonal entries in italic), and the $A V E$ values for all constructs were greater than their $M S V$ values, affirming that discriminant validity was established.

\section{Common Method Variance}

Common method variance (CMV) can be defined as the "variance that is attributable to the measurement method rather than to the constructs the measures represent" (Podsakoff et al., 2003, p. 879). CMV may produce a false internal consistency and intercorrelations that affect the validity of the results (Malhotra et al., 2006). This means that significant results from the relationships between constructs may be due to CMV instead of actual hypothesized effects. In this study, the issue of CMV was assessed as per the suggestion of Malhotra et al. (2006), who stated that CMV is not a problem if all the measurement items modeled as a single factor do not fit. Following this guideline, the single factor analysis revealed that the model did not fit; hence, it was ascertained that CMV was not an issue in this study. Having addressed and satisfied the criteria for validity, reliability, and $\mathrm{CMV}$, the subsequent section presents the results of the structural model and hypotheses testing.

\section{Structural Model Assessment and Hypotheses Testing}

The SEM technique was used to assess the structural model of the present study. SEM is commonly used by researchers to examine the overall fit of a structural model and to test its individual causal paths (Hair et al., 2010). The structural model depicted in Figure 1 portrays that the model's $\chi^{2} / d f$ was 2.192, GFI was .870, RMSEA was .055, TLI was .918, and PNFI was .793, indicating that the structural model had reasonable fit. Table 2 presents the hypothesized direct path results, which were found to be significant and in support of Hypotheses 1 to 7. Specifically, hotels' relationship marketing was found to have a significant positive impact on perceived service quality $(\beta=.351, p<$ $.001)$, corporate image $(\beta=.291, p<.001)$, and customer satisfaction $(\beta=$ 
Table 2

Result of Path Analysis

\begin{tabular}{lccc}
\hline Hypothesized Path & $\begin{array}{c}\text { Standardized } \\
\text { Estimate }(\beta)\end{array}$ & $\begin{array}{c}\text { Critical } \\
\text { Ratio }\end{array}$ & Significant \\
\hline $\begin{array}{l}\text { Hypothesis 1: Relationship marketing } \\
\rightarrow \text { Perceived service quality }\end{array}$ & .351 & $5.814^{* *}$ & Yes \\
$\begin{array}{l}\text { Hypothesis 2: Relationship marketing } \\
\quad \rightarrow \text { Corporate image }\end{array}$ & .291 & $4.687^{* *}$ & Yes \\
$\begin{array}{l}\text { Hypothesis 3: Perceived service } \\
\quad \text { quality } \rightarrow \text { Corporate image }\end{array}$ & .215 & $3.444^{* *}$ & Yes \\
$\begin{array}{l}\text { Hypothesis 4: Corporate image } \rightarrow \\
\quad \text { Customer loyalty }\end{array}$ & .398 & $6.427^{* *}$ & Yes \\
$\begin{array}{l}\text { Hypothesis 5: Relationship marketing } \\
\rightarrow \text { Customer satisfaction }\end{array}$ & .239 & $4.199^{* *}$ & Yes \\
$\begin{array}{l}\text { Hypothesis 6: Perceived service } \\
\text { quality } \rightarrow \text { Customer satisfaction }\end{array}$ & .315 & $5.194^{* *}$ & Yes \\
$\begin{array}{l}\text { Hypothesis 7: Customer satisfaction } \\
\rightarrow \text { Customer loyalty }\end{array}$ & .239 & $4.390^{* *}$ & Yes \\
\hline
\end{tabular}

${ }^{* *}$ Significant at $99 \%$ confidence level.

$.239, p<.001)$. Similarly, hotel guests' perceived service quality was found to have a significant positive impact on their satisfaction $(\beta=.315, p<.001)$ and their image of the hotel $(\beta=.215, p<.001)$. The results also indicate that both corporate image $(\beta=.398, p<.001)$ and customer satisfaction $(\beta=.239, p<$ $.001)$ positively influence guests' loyalty toward the hotel they stayed in during their trip.

\section{Multiple Group Analysis}

Multiple group analysis (MGA) was used to examine the differences between Asian and Western tourists in relation to the causal paths in the structural model. The MGA analysis was performed based on the guidelines proposed by Jöreskog and Sörbom (1993). It began by splitting the data into two cultural groups, that is, Asian and Western. Next, SEM analysis was performed on the structural model whereby all the causal paths were fixed with equal regression weights for both groups. Then, another SEM analysis was conducted without imposing any equality constraints for the causal paths, such that they were freely estimated. Last, the significance of the moderating effect of culture on all the causal paths was determined based on the chi-square difference test. The moderating effect of culture was deemed to exist when the path coefficient's critical value was greater than 3.841 at the $95 \%$ confidence level.

Further analysis was conducted to determine the differences between the structural models of the Asian and Western groups. The results found that both the Asian group $\left(\chi^{2} / d f=1.606, \mathrm{GFI}=.833\right.$, RMSEA $=.055, \mathrm{TLI}=$ 
Table 3

Results of Multiple Group Analysis

\begin{tabular}{lccccc}
\hline $\begin{array}{l}\text { Hypothesis and Path } \\
\text { Name }\end{array}$ & $\begin{array}{c}\text { Asian } \\
(\beta)\end{array}$ & $\begin{array}{c}\text { Western } \\
(\beta)\end{array}$ & $\begin{array}{c}\text { Difference } \\
\text { in } \beta\end{array}$ & $p$ Value & Significant \\
\hline Hypothesis 8: RM $\rightarrow \mathrm{PSQ}$ & $.178^{\star}$ & $.508^{\star \star}$ & -.330 & .019 & Yes \\
Hypothesis 9: RM $\rightarrow \mathrm{Cl}$ & $.268^{\star}$ & $.272^{\star}$ & -.004 & .929 & No \\
Hypothesis 10: PSQ $\rightarrow \mathrm{Cl}$ & $.266^{\star}$ & $.254^{\star}$ & .012 & .843 & No \\
Hypothesis 11: Cl $\rightarrow \mathrm{CL}$ & $.348^{\star \star}$ & $.322^{\star \star}$ & .026 & .796 & No \\
Hypothesis 12: RM $\rightarrow \mathrm{CS}$ & $.128^{\text {ns }}$ & $.327^{\star \star}$ & -.199 & .218 & No \\
Hypothesis 13: PSQ $\rightarrow \mathrm{CS}$ & $.279^{\star *}$ & $.438^{\star \star}$ & -.159 & .378 & No \\
Hypothesis 14: CS $\rightarrow \mathrm{CL}$ & $.163^{\star}$ & $.372^{\star \star}$ & -.209 & .018 & Yes \\
\hline
\end{tabular}

Note: $\mathrm{RM}=$ Relationship marketing; $\mathrm{PSQ}=$ perceived service quality; $\mathrm{CS}=$ customer satisfaction; $\mathrm{Cl}=$ corporate image; $\mathrm{CL}=$ customer loyalty; $\mathrm{ns}=$ not significant. *Significant at $99 \%$ confidence level.

${ }^{* \star}$ Significant at $95 \%$ confidence level.

.900 , and PNFI $=.722)$ and the Western group $\left(\chi^{2}=243.334, d f=182\right.$, CFI $=.978, \mathrm{IFI}=.979, \mathrm{RMSEA}=.052)$ had reasonable fit. As highlighted in the online Supplemental Table 3, the $p$ value of .000 indicated that the chi-square difference between the nonconstraint model and the constraint model was significant, suggesting that the model differed across Asian and Western hotel guests.

To analyze the moderating effect of culture as postulated in Hypotheses 8 to 14, a chi-square difference test was used to evaluate the differences in each of the seven path coefficients. Table 3 exhibits that only two paths were found to be significant. In particular, the $p$ value of .019 reflects the significant difference between Asian and Western tourists in the effect of relationship marketing on perceived service quality, whereby the effect is stronger for Western hotel guests $(\beta=.508)$. Similarly, the influence of customer satisfaction on customer loyalty was also found to significantly vary across Asian and Western groups ( $p$ value $=$ .018), such that this influence is more evident for Western hotel guests than their Asian counterparts.

\section{DISCUSSION}

This study's findings are in agreement with previous studies by Kinard and Capella (2006) and Sadeghi et al. (2017) that verified the influence of relationship marketing on customers' perceived service quality, proving that customer-employee interactions are a crucial area for firms' focused efforts. Corroborating the work of Bennett and Barkensjo (2005) and Christian et al. (2017), relationship marketing was found to play a fundamental role in the formation of a hotel's corporate image. Employees' ability to manage customer relationships and interactions are therefore deemed essential in establishing organizational image. The results further showcased a positive link 
between relationship marketing and customer satisfaction, in line with the findings of Gunjan (2018) and W. G. Kim and Cha (2002). Specifically, employees' responsiveness to complaints and requests emerged as the most influential element of customer satisfaction (Gunjan, 2018; Meesala \& Paul, 2018). Overall, well-implemented relationship marketing can beget positive reciprocated behaviors from customers (Ryu \& Lee, 2017), which demonstrates the relevance of relationship marketing to today's marketing efforts (Arminda \& Sergio, 2017).

The direct influence of perceived service quality on customer satisfaction is also in congruence with past studies (Kant \& Jaiswal, 2017; Miranda et al., 2018; Parasuraman et al., 1988). Marković and Janković (2013) presented similar findings in the tourism and hotel industry as well. Furthermore, perceived service quality was confirmed as a direct antecedent to hotels' corporate image, consistent with the findings of Ladhari et al. (2011) and Mohsin and Lockyer (2010). Evidently, service experience is an essential component of customers' perceptions toward both service quality and overall corporate image (W. J. Chen \& Chen, 2014; Mohsin \& Lockyer, 2010).

Consistent with the results of Christou (2003) and Cheng and Rashid (2015), corporate image was determined to possess a positive influence on customer loyalty. Additionally, customer satisfaction was affirmed to be a prerequisite to loyalty. This does not just support earlier studies (Marković \& Janković, 2013; Martínez \& Bosque, 2013) but also highlights that loyalty from satisfied customers is highly profitable to a service organization.

Notably, cultural differences between Asian and Western tourists demonstrated significant impacts on the links between (1) relationship marketing and perceived service quality and (2) customer satisfaction and customer loyalty. Deng et al. (2019) and Paris et al. (2014) posited that certain destination qualities transcend cultural influences and hold equal importance among Asian and Western tourists. Yet the current findings have revealed dissimilarities in service perceptions between Asian and Western tourists. This disparity is prevalent due to the collectivistic nature of Asian tourists; they emphasize interpersonal benefits over monetary benefits and therefore evaluate service excellence based on a pleasant employee-customer relationship (Williams et al., 2017). Indeed, the human factor has been highly regarded among Asian tourists (Reisinger \& Turner, 2002), leading them to rely more heavily than Westerners on the "personal factor" in evaluating the service quality of their travel accommodation. Seo (2012) substantiated this notion by highlighting that Western tourists are less concerned about service-oriented aspects than Asians. The significance of cultural differences is, as such, dependent on dissimilar elements of an experienced service. While the positive impact of customer satisfaction on loyalty applies to both Western and Asian tourists, the current study expanded the findings of Weber et al. (2017) by discovering the greater importance of a positive hotel experience to stimulate loyalty among tourists of Asian origin. 


\section{THEORETICAL IMPLICATIONS}

The constructs of relationship marketing, perceived service quality, corporate image, satisfaction, and loyalty have been extensively studied by scholars. The extant literature has reported diverging relationships between these constructs based on the contexts under investigation (Anggraini et al., 2016; Bennett \& Barkensjo, 2005; E. L.-Y. Li et al., 2017). For instance, while E. L.-Y. Li et al. (2017) claimed that the influence of customers' trust on loyalty was only applicable in the low-contact service sector, most findings relate to the service industry in general. The current study, therefore, offers insights into the hotel industry as a pertinent and apt representation of the high-contact service industry.

Generally, customer experience within the high-context sector is explained by the expectancy-disconfirmation theory (Cadotte et al., 1987). Fulfilling substantial requests from tourists of diverse origins is a critical priority for hotel operators and their staff. This places the industry as a highly interactive one rather than a one-way delivery industry. High-contact service employees, such as hotel employees, should therefore cultivate customer relationships for longterm profitability. While it might not surpass health care's level of contact, the implications of this study on hotels are nevertheless relevant for contextual and conditional service firms. Overall, this study contributes to the literature on long-term customer retention and customer perceptions in high-contact services. Moreover, it establishes cultural background as a vital element of customers' perceptions and individual requirements.

\section{PRACTICAL IMPLICATIONS}

Customers' perceptions of a satisfactory travel experience can be traced to their underlying behaviors formed by their nationalities. Behavioral differences in terms of traveling goals and preferences (e.g., spending patterns, leisure undertakings, and social relations) have been clearly observed between tourists from Asian and Western countries (Özdemir \& Yolal, 2016). In the context of cross-cultural business, cultural values upheld in information transparency, value-added capabilities, and relational norms would determine customer loyalty (Skarmeas et al., 2016). As opposed to W. Kim and Malek's (2016) work, geographical congruency registered a higher standing among Asians than Westerners. Asian tourists are less tolerable in both affective (relationship with hotel staff) and conative (actual service received) perceptions towards hotels' services, while Western tourists are more tolerant. While homogeneity was seen in other relationships, Asian tourists hold stricter standards when it comes to employee-customer relationships and satisfaction-based loyalty; thus, extensive and culturally customized services are required to establish conducive relationships with Asian customers to enhance long-term competitiveness.

Given the importance of cultural differences, destination marketing organizations, along with other industry players, must consider the differences in tourists' attitudes, behaviors, and culture when segmenting tourist markets 
and developing appropriate marketing strategies for each market. To attract Asian tourists, hotel management should focus on consistency in relationship marketing efforts to create positive perceptions of service quality. For example, implementing excellent customer service strategies by engaging personalized interactions and understanding the needs of customers can enhance relationship marketing initiatives. Besides, management should also focus on the role of customer satisfaction in attracting Asian customers, given that satisfaction drives loyalty. As such, hotels should strive to increase Asian tourists' customer satisfaction by improving their service delivery and customers' service experience. In particular, having a standard of procedures for service delivery along with a supportive workplace culture would be effective in fostering employees' motivation and performance in meeting customers' expectations.

\section{LIMITATIONS AND CONCLUSION}

Despite the implications discussed above, the present study is subjected to several limitations. Primary limitation revealed the study's sole focus on the service industry, which restricts the applicability and generalizability of the results toward other contexts. This is especially true in consideration of the intangible nature of services that differs from tangible products, leading to vast divergences in consumer experience. Hence, future studies can opt to replicate this study in other research contexts. The second limitation further highlights this study's findings to possess narrowed generalizability to different classes of hotels, although all hotels are classified as part of the high-contact service industry in this study. All classes of hotels may not share this study's findings due to contrasting customer bases, as these customers may possibly hold dissimilar expectations for service quality. Hence, future research can consider focusing on a single hotel class (i.e., budget hotel or luxury hotel) as a more specified area of study. Moreover, future studies can also account for the possible mediating effects of corporate image, service quality, and customer satisfaction on the relationship between relationship marketing and customer loyalty.

In conclusion, this study has contributed to the body of knowledge on service marketing by highlighting the importance of relationship marketing, service quality, corporate image, customer satisfaction, and loyalty in the hospitality setting. In an industry where constant and consistent employee-customer interactions are the key to balancing expectations and outcomes, the findings show that all these elements are vital in promoting international tourists' loyalty toward hotels in Malaysia. Moreover, understanding the cultural differences between Asian and Western tourists is imperative for hotels in retaining their existing customers and remaining aware of industrial needs. Taking all these into consideration, closer attention should be paid and further studies should be conducted by all relevant parties in this industry to collectively promote Malaysia as a favorable tourism destination in the global arena. 


\section{ORCID iDs}

Tat-Huei Cham (iD https://orcid.org/0000-0001-7636-5928

Hiram Ting (iD https://orcid.org/0000-0002-1389-976X

\section{SUPPLEMENTAL MATERIAL}

Supplemental material for this article is available online.

\section{REFERENCES}

Ali, F., Hussain, K., Konar, R., \& Jeon, H.-M. (2017). The effect of technical and functional quality on guests' perceived hotel service quality and satisfaction: A SEM-PLS analysis. Journal of Quality Assurance in Hospitality \& Tourism, 18(3), 354-378. https://doi.org/10.1080/1528008X.2016.1230037

Al-Nazer, N. (2010). Investigate the impact of relationship marketing orientation on customer loyalty: The customer's perspective. International Journal of Marketing Studies, 2(1), 155-174. https://doi.org/10.5539/ijms.v2n1p155

Andrades-Caldito, L., Sánchez-Rivero, M., \& Pulido-Fernández, J. I. (2014). Tourism destination competitiveness from a demand point of view: An empirical analysis for Andalusia. Tourism Analysis, 19(4), 425-440. https://doi.org/10.3727/1083542 14X14090817031035

Anggraini, W. S., Haryono, A. T., \& Hasiholan, L. B. (2016). Influence of customer relationship marketing, service quality and corporate image of the customer customer retention graha candi golf semarang (with satisfaction as an intervening variable). Journal of Management, 2(2). https://jurnal.unpand.ac.id/index.php/MS/article/view $1541 / 527$

Arminda, A. S., \& Sergio, M. G. (2017). New trends in information search and their influence on destination loyalty: Digital destinations and relationship marketing. Journal of Destination Marketing \& Management, 6(2), 150-161. https://doi.org/10.1016/j. jdmm.2017.02.003

Association for Supply Chain Management. (2020). APICS operations management body of knowledge framework (3rd ed.). https://www.apics.org/apics-for-individuals/ apics-magazine-home/resources/ombok/apics-ombok-framework-table-of-contents/ apics-ombok-framework-4.3

Azhar, M. S., Othman, I. B. L., \& Ahmad, N. (2018). A conceptual framework on customer satisfaction: The mediating role of corporate image. Global Social Science Review, 3(4), 254-272. https://doi.org/10.31703/gssr.2018(III-IV).17

Beetles, A. C., \& Harris, L. C. (2010). The role of intimacy in service relationships: An exploration. Journal of Services Marketing, 24(5), 347-358. https://doi.org $/ 10.1108 / 08876041011060459$

Bennett, R., \& Barkensjo, A. (2005). Relationship quality, relationship marketing, and client perceptions of the levels of service quality of charitable organisations. International Journal of Service Industry Management, 16(1), 81-106. https://doi. org/10.1108/09564230510587168

Berezan, O., Krishen, A. S., Tanford, S., \& Raab, C. (2017). Style before substance? Building loyalty through marketing communication congruity. European Journal of Marketing, 51(7/8), 1332-1352. https://doi.org/10.1108/EJM-06-2015-0314 
Bowen, J. T., \& Chen, S. L. (2001). The relationship between customer loyalty and customer satisfaction. International Journal of Contemporary Hospitality Management, 13(5), 213-217. https://doi.org/10.1108/09596110110395893

Briggs, S., Sutherland, J., \& Drummond, S. (2007). Are hotels serving quality? An exploratory study of service quality in the Scottish hotel sector. Tourism Management, 28(4), 1006-1019. https://doi.org/10.1016/j.tourman.2006.08.015

Cadotte, E. R., Woodruff, R. B., \& Jenkins, R. L. (1987). Expectations and norms in models of consumer satisfaction. Journal of Marketing Research, 24(3), 305-314. https://doi.org/10.1177/002224378702400307

Cham, T. H., Cheng, B. L., Low, M. P., \& Cheok, J. B. C. (2020). Brand image as the competitive edge for hospitals in medical tourism. European Business Review, 33(1), 31-59. https://doi.org/10.1108/EBR-10-2019-0269

Cham, T. H., Cheng, B. L., \& Ng, C. K. Y. (2020). Cruising down millennials' fashion runway: A cross-functional study beyond Pacific borders. Young Consumers. Advance online publication. https://doi.org/10.1108/YC-05-2020-1140

Cham, T. H., \& Easvaralingam, Y. (2012). Service quality, image and loyalty towards Malaysian hotels. International Journal of Services, Economics and Management, 4(4), 267-281. https://doi.org/10.1504/IJSEM.2012.050951

Cham, T. H., Lim, Y. M., Aik, N. C., \& Tay, A. G. M. (2016). Antecedents of hospital brand image and the relationships with medical tourists' behavioral intention. International Journal of Pharmaceutical and Healthcare Marketing, 10(4), 412-431. https://doi.org/10.1108/IJPHM-02-2016-0012

Cham, T. H., Lim, Y. M., Sia, B. C., Cheah, J. H., \& Ting, H. (2021). Medical tourism destination image and its relationship with the intention to revisit: A study of Chinese medical tourists in Malaysia. Journal of China Tourism Research, 17(2), 163-191. https://doi.org/10.1080/19388160.2020.1734514

Chan, W. W. H., Chow, C. W. C., Loi, R., \& Xu, A. J. (2018). Turning hotel employees into brand champions: The roles of well-connected leaders and organisational identification. Journal of Hospitality \& Tourism Research, 42(8), 1232-1253. https://doi. org/10.1177/1096348017744017

Chen, G., Shi, J., Xia, Y., \& Furuya, K. (2020). The sustainable development of urban cultural heritage gardens based on tourists' perception: A case study of Tokyo's Cultural Heritage Gardens. Sustainability, 12(16), 6315. https://doi.org/10.3390/ su12166315

Chen, W. J., \& Chen, M. L. (2014). Factors affecting the hotel's service quality: Relationship marketing and corporate image. Journal of Hospitality Marketing \& Management, 23(1), 77-96. https://doi.org/10.1080/19368623.2013.766581

Cheng, B. L., Cham, T. H., Micheal, D., \& Lee, T. H. (2019). Service innovation: Building a sustainable competitive advantage in higher education. International Journal of Services, Economics and Management, 10(4), 289-309. https://doi.org/10.1504/ IJSEM.2019.105014

Cheng, B. L., Gan, C. C., Imrie, B. C., \& Mansori, S. (2019). Service recovery, customer satisfaction and customer loyalty: Evidence from Malaysia's hotel industry. International Journal of Quality and Service Sciences, 11(2), 187-203. https://doi. org/10.1108/IJQSS-09-2017-0081

Cheng, B. L., Mansori, S., \& Cham, T. H. (2014). The associations between service quality, corporate image, customer satisfaction, and loyalty: Evidence from the Malaysian 
hotel industry. Journal of Hospitality Marketing \& Management, 23(3), 314-326. https://doi.org/10.1080/19368623.2013.796867

Cheng, B. L., Mansori, S., Gan, C. C., \& Imrie, B. C. (2017). Hotel service recovery and service quality: Influences of corporate image and generational differences in the relationship between customer satisfaction and loyalty. Journal of Global Marketing, 30(1), 42-51. https://doi.org/10.1080/08911762.2016.1262932

Cheng, B. L., \& Rashid, Z. A. (2015). Interrelationships of service quality, customer satisfaction, corporate image and customer loyalty of Malaysian hotel industry. In Cultural tourism in a digital era (pp. 37-38). Springer, Cham. https://doi.org/10.1007/978-3319-15859-4_3

Choi, T. Y., \& Chu, R. (2000). Level of satisfaction between Asian and Western travelers. International Journal of Quality and Reliability Management, 17(2), 116-131. https://doi.org/10.1108/02656710010304537

Chou, S., \& Chen, C.-W. (2018). The influences of relational benefits on repurchase intention in service contexts: The roles of gratitude, trust and commitment. Journal of Business \& Industrial Marketing, 33(5), 680-692. https://doi.org/10.1108/JBIM08-2017-0187

Christian, O. O., Aghara, V. N. O., \& Obianuju, E. (2017). Effect of relationship marketing and relationship marketing programs on customer loyalty. International Journal of Business and Management Review, 5(5), 58-71. https://www.eajournals.org/wpcontent/uploads/Effect-of-Relationship-Marketing-and-Relationship-MarketingPrograms-on-Customer-Loyalty.pdf

Christou, E. (2003). Guest loyalty likelihood in relation to hotels' corporate image and reputation: A study of three countries in Europe. Journal of Hospitality \& Leisure Marketing, 10(3-4), 85-99. https://doi.org/10.1300/J150v10n03_05

Chun, R. (2005). Corporate reputation: Meaning and measurement. International Journal of Management Reviews, 7(2), 91-109. https://doi.org/10.1111/j.1468-2370.2005.00109.x

Dedeoğlu, B. B., Küçükergin, K. G., \& Balıkçıoglu, S. (2015). Understanding the relationships of servicescape, value, image, pleasure, and behavioural intentions among hotel customers. Journal of Travel \& Tourism Marketing, 32(1), 42-61. https://doi.org /10.1080/10548408.2014.982268

Deng, N., Liu, J. Y., Dai, Y., \& Li, H. (2019). Different cultures, different photos: A comparison of Shanghai's pictorial destination image between East and West. Tourism Management Perspectives, 30, 182-192. https://doi.org/10.1016/j.tmp.2019.02.016

Engriani, Y., Permatasari, M., Abror, A., \& Patrisia, D. (2019). The link between service quality, corporate image and behavioral intention: Satisfaction as an intervening variable. International Journal of Modern Trends in Social Sciences, 2(8), 119-131. https://doi.org/10.35631/IJMTSS.280012

Faul, F., Erdfelder, E., Buchner, A., \& Lang, A. G. (2009). Statistical power analyses using $\mathrm{G}^{*}$ Power 3.1: Tests for correlation and regression analyses. Behavior Research Methods, 41(4), 1149-1160. https://doi.org/10.3758/BRM.41.4.1149

Fornell, C., \& Larcker, D. F. (1981). Structural equation models with unobservable variables and measurement error: Algebra and statistics. Journal of Marketing Research, 18(3), 382-388. https://doi.org/10.1177/002224378101800313

Gallo, A. (2014, October 29). The value of keeping the right customers. Harvard Business Review. https://hbr.org/2014/10/the-value-of-keeping-the-right-customers

Ganesan, V. (2018, September 14). 2018-2020 Tourist arrival, receipt targets lowered. https:// www.theedgemarkets.com/article/20182020-tourist-arrival-receipt-targets-lowered 
Grönroos, C. (1988). Service quality: The six criteria of good perceived service. Review of Business, 9(3), 10-13.

Gunjan, M. (2018). Relationship between customer relationship management and customer satisfaction: A case study of five star hotels in NCR. TRANS Asian Journal of Marketing \& Management Research, 7(4), 23-33.

Hair, J. F. J., Black, W. C., Babin, B. J., Anderson, R. E., \& Tatham, R. L. (2010). Multivariate data analysis a global perspective. Pearson Education International.

Hapsari, R., Clemes, M. D., \& Dean, D. (2017). The impact of service quality, customer engagement and selected marketing constructs on airline passenger loyalty. International Journal of Quality and Service Sciences, 9(1), 21-40. https://doi. org/10.1108/IJQSS-07-2016-0048

Harker, M. J. (1999). Relationship marketing defined? An examination of current relationship marketing definitions. Marketing Intelligence \& Planning, 17(1), 13-20. https://doi.org/10.1108/02634509910253768

Harris, L. C., \& Goode, M. M. (2004). The four levels of loyalty and the pivotal role of trust: A study of online service dynamics. Journal of Retailing, 80(2), 139-158. https://doi.org/10.1016/j.jretai.2004.04.002

Hennig-Thurau, T., \& Hansen, U. (Eds.). (2013). Relationship marketing: Gaining competitive advantage through customer satisfaction and customer retention. Springer Science \& Business Media.

Holmlund, M., \& Kock, S. (2006). Relationship marketing: The importance of customerperceived service quality in retail banking. Service Industries Journal, 16(3), 287304. https://doi.org/10.1080/02642069600000029

Hospitality Net. (2020). Tourism satisfaction: Importance, measurability \& impacts. https://www.hospitalitynet.org/news/4096450.html

Hu, H. H., Kandampully, J., \& Juwaheer, T. D. (2009). Relationships and impacts of service quality, perceived value, customer satisfaction, and image: An empirical study. Service Industries Journal, 29(2), 111-125. https://doi.org/10.1080/02642060802292932

Infosurv. (2006). 5-point vs. 6-point Likert scales. https://www.infosurv.com/whitepaper-5-point-vs-6-point-likert-scales/

Jiang, H., \& Zhang, Y. (2016). An investigation of service quality, customer satisfaction and loyalty in China's airline market. Journal of Air Transport Management, 57, 8088. https://doi.org/10.1016/j.jairtraman.2016.07.008

Jin, Q., Hu, H., \& Kavan, P. (2016). Factors influencing perceived crowding of tourists and sustainable tourism destination management. Sustainability, 8(10), Article 976. https://doi.org/10.3390/su8100976

Johns, R. (2010). Likert items and scales. https://ukdataservice.ac.uk/media/262829/ discover_likertfactsheet.pdf?utm_source=buffer\&utm_campaign=Buffer\&utm content=-buffer3af8d\&utm_medium $=$ twitter

Jöreskog, K. G., \& Sörbom, D. (1993). LISREL 8: Structural equation modeling with the SIMPLIS command language. Scientific Software International.

Joseph, N. B. (2018, January 11). More work needed even though KKIA second busiest airport-Masidi. The Borneo Post. https://www.theborneopost.com/2018/01/11/ more-work-needed-even-though-kkia-second-busiest-airport-masidi/

Kandampully, J., Juwaheer, T. D., \& Hu, H. H. (2011). The influence of a hotel firm's quality of service and image and its effect on tourism customer loyalty. International Journal of Hospitality \& Tourism Administration, 12(1), 21-42. https://doi.org/10.10 80/15256480.2011.540976 
Kant, R., \& Jaiswal, D. (2017). The impact of perceived service quality dimensions on customer satisfaction: An empirical study on public sector banks in India. International Journal of Bank Marketing, 35(3), 411-430. https://doi.org/10.1108/ IJBM-04-2016-0051

Kasiri, L. A., Cheng, K. T. G., Sambasivan, M., \& Sidin, S. M. (2017). Integration of standardization and customization: Impact on service quality, customer satisfaction, and loyalty. Journal of Retailing and Consumer Services, 35(C), 91-97. https://doi. org/10.1016/j.jretconser.2016.11.007

Keiningham, T. L., Cooil, B., Aksoy, L., Andreassen, T. W., \& Weiner, J. (2007). The value of different customer satisfaction and loyalty metrics in predicting customer retention, recommendation, and share-of-wallet. Managing Service Quality: An International Journal, 17(4), 361-384. https://doi.org/10.1108/09604520710760526

Kim, W., \& Malek, K. (2016). Effects of self-congruity and destination image on destination loyalty: The role of cultural differences. Anatolia: An International Journal of Tourism and Hospitality Research, 28(1), 1-13. https://doi.org/10.1080/13032917.2016.1239209

Kim, W. G., \& Cha, Y. (2002). Antecedents and consequences of relationship quality in hotel industry. International Journal of Hospitality Management, 21(4), 321-338. https://doi.org/10.1016/S0278-4319(02)00011-7

Kim, W. G., Han, J. S., \& Lee, E. (2001). Effects of relationship marketing on repeat purchase and word of mouth. Journal of Hospitality \& Tourism Research, 25(3), 272288. https://doi.org/10.1177/109634800102500303

Kinard, B. R., \& Capella, M. L. (2006). Relationship marketing: The influence of consumer involvement on perceived service benefits. Journal of Services Marketing, 20(6), 359-368. https://doi.org/10.1108/08876040610691257

Kulas, J. T., Stachowski, A. A., \& Haynes, B. A. (2008). Middle response functioning in Likert-responses to personality items. Journal of Business and Psychology, 22(3), 251-259. https://doi.org/10.1007/s10869-008-9064-2

Lacap, J. P. G., Cham, T. H., \& Lim, X. J. (2021). The influence of corporate social responsibility on brand loyalty and the mediating effects of brand satisfaction and perceived quality. International Journal of Economics and Management, 15(1), 69-87.

Ladhari, R., Souiden, N., \& Ladhari, I. (2011). Determinants of loyalty and recommendation: The role of perceived service quality, emotional satisfaction and image. Journal of Financial Services Marketing, 16(2), 111-124. https://doi.org/10.1057/fsm.2011.10

Leveren, A., \& Liljander, V. (2006). Does relationship marketing improve customer relationship satisfaction and loyalty? International Journal of Bank Marketing, 24(4), 232-251. https://doi.org/10.1108/02652320610671333

Li, C. K., \& Hung, C. H. (2009). Marketing tactics and parents' loyalty: The mediating role of school image. Journal of Educational Administration, 47(4), 477-489. https:// doi.org/10.1108/09578230910967455

Li, E. L.-Y., Liu, B. S.-C., \& Luk, S. T. K. (2017). Customer participation behavior in high-versus low-contact services: The multiple roles of customer trust. Journal of Global Marketing, 30(5), 322-341. https://doi.org/10.1080/08911762.2017.1343886

Li, M. (2014). Cross-cultural tourist research: A meta-analysis. Journal of Hospitality Tourism Research, 38(1), 40-77. https://doi.org/10.1177/1096348012442542

Lim, X. J., Cheah, J. H., Cham, T. H., Ting, H., \& Memon, M. A. (2020). Compulsive buying of branded apparel, its antecedents, and the mediating role of brand attachment. Asia Pacific Journal of Marketing and Logistics, 32(7), 1539-1563. https://doi.org/10.1108/ APJML-03-2019-0126 
Lim, X. J., Ng, S. I., Chuah, F., Cham, T. H., \& Rozali, A. (2019). I see, and I hunt: The link between gastronomy online reviews, involvement and behavioural intention towards ethnic food. British Food Journal, 122(6), 1777-1800. https://doi. org/10.1108/BFJ-07-2018-0459

Lim, Y. M., Cham, T. H., \& Sia, B. C. (2018). Medical tourists' behavioral intention in relation to motivational factors and perceived image of the service providers. International Academic Journal of Organizational Behavior and Human Resource Management, 5(3), 1-16.

Lock, S. (2020a). Tourism worldwide-Statistics \& facts. Statista. https://www.statista. com/topics/962/global-tourism/

Lock, S. (2020b). Travel and tourism industry revenue in selected countries in 2019 and projected impact of the coronavirus (COVID-19) pandemic in 2020. https://www. statista.com/forecasts/1103432/covid-19-revenue-travel-tourism-industry-countryforecast

Luarn, P., \& Lin, H. H. (2005). Toward an understanding of the behavioral intention to use mobile banking. Computers in Human Behavior, 21(6), 873-891. https://doi. org/10.1016/j.chb.2004.03.003

Magatef, S. G., \& Tomalieh, E. F. (2015). The impact of customer loyalty programs on customer retention. International Journal of Business and Social Science, 6(8), 78-93.

Malhotra, N. K. (2004). Marketing research-An applied orientation (4th ed.). PrenticeHall.

Malhotra, N. K., Kim, S. S., \& Patil, A. (2006). Common method variance in IS research: A comparison of alternative approaches and a reanalysis of past research. Management Science, 52(12), 1865-1883. https://doi.org/10.1287/mnsc.1060.0597

Marković, S., \& Janković, R. S. (2013). Exploring the relationship between service quality and customer satisfaction in Croatian hotel industry. Tourism and Hospitality Management, 19(2), 149-164. https://doi.org/10.20867/thm.19.2.1

Martínez, P., \& Bosque, I. R. D. (2013). CSR and customer loyalty: The roles of trust, customer identification with the company and satisfaction. International Journal of Hospitality Management, 35, 89-99. https://doi.org/10.1016/j.ijhm.2013.05.009

Meesala, A., \& Paul, J. (2018). Service quality, consumer satisfaction and loyalty in hospitals: Thinking for the future. Journal of Retailing and Consumer Services, 40, 261-269.

Memon, M. A., Ting, H., Cheah, J. H., Ramayah, T., Chuah, F., \& Cham, T. H. (2020). Sample size for survey research: Review and recommendations. Journal of Applied Structural Equation Modelling, 4(2), 1-20. https://doi.org/10.47263/JASEM.4(2)01

Milan, G. S., Eberle, L., \& Bebber, S. (2015). Perceived value, reputation, trust, and switching costs as determinants of customer retention. Journal of Relationship Marketing, 14(2), 109-123. https://doi.org/10.1080/15332667.2015.1041353

Miranda, S., Tavares, P., \& Queiró, R. (2018). Perceived service quality and customer satisfaction: A fuzzy set QCA approach in the railway sector. Journal of Business Research, 89(C), 371-377. https://doi.org/10.1016/j.jbusres.2017.12.040

Mohsin, A., \& Lockyer, T. (2010). Customer perceptions of service quality in luxury hotels in New Delhi, India: An exploratory study. International Journal of Contemporary Hospitality Management, 22(2), 160-173. https://doi.org/10.1108 /09596111011018160 
Mostafa, R. (2017). Does corporate image really matter in service recovery context? International Journal of Customer Relationship Marketing and Management, 8(1), Article 1. https://doi.org/10.4018/IJCRMM.2017010101

Murphy, L., Benckendorff, P., \& Moscardo, G. (2007). Destination brand personality: Visitor perceptions of a regional tourism destination. Tourism Analysis, 12(5-6), 419-432. https://doi.org/10.3727/108354207783227948

Narteh, B., Agbemabiese, G. C., Kodua, P., \& Braimah, M. (2013). Relationship marketing and customer loyalty: Evidence from the Ghanaian luxury hotel industry. Journal of Hospitality Marketing \& Management, 22(4), 407-436. https://doi.org/10.1080/19 368623.2012.660564

Olorunniwo, F., Hsu, M. K., \& Udo, G. J. (2006). Service quality, customer satisfaction, and behavioural intentions in the service factory. Journal of Services Marketing, 20(1), 59-72. https://doi.org/10.1108/08876040610646581

Onkvisit, S., \& Shaw, J. J. (1989). Service marketing: image, branding, and competition. Business Horizons, 32(1), 13-19. https://doi.org/10.1016/0007-6813(89)90018-9

Open Access Publisher. (2020). Elements-of-the-tourism-industry. https://www.omicsonline.org/elements-of-the-tourism-industry.php

Ottenbacher, M., Gnoth, J., \& Jones, P. (2006). Identifying determinants of success in development of new high-contact services. International Journal of Service Industry Management, 17(4), 344-363. https://doi.org/10.1108/09564230610680659

Özdemir, C., \& Yolal, E. M. (2016). Cross-cultural tourist behavior: An examination of tourists' behavior in guided tours. Tourism and Hospitality Research, 17(3), 314-324. https://doi.org/10.1177/1467358415589658

Palmatier, R. W. (2008). Relationship marketing. Marketing Science Institute.

Panjaitan, H., \& Laely, N. (2017). The role of relationship marketing, and satisfaction as variable mediation: Study at Bank BPR UMKM East Java in Surabaya. International Review of Management and Marketing, 7(5), 105-112.

Parasuraman, A., Zeithaml, V. A., \& Berry, L. L. (1988). SERVQUAL: A multiple-item scale for measuring consumer perceptions of service quality. Journal of Retailing, 64(1), 12-40.

Paris, C. M., Musa, G., \& Thirumoorthi, T. (2014). A comparison between Asian and Australasia backpackers using cultural consensus analysis. Current Issues in Tourism, 18(2), 175-195. https://doi.org/10.1080/13683500.2014.920771

Podsakoff, P. M., MacKenzie, S. B., Lee, J. Y., \& Podsakoff, N. P. (2003). Common method biases in behavioral research: A critical review of the literature and recommended remedies. Journal of Applied Psychology, 88(5), 879-903. https://doi. org/10.1037/0021-9010.88.5.879

Rahimi, R., \& Kozak, M. (2015). Impact of customer relationship management on customer satisfaction: The case of a budget hotel chain. Journal of Travel \& Tourism Marketing, 34(1), 40-51. https://doi.org/10.1080/10548408.2015.1130108

Reisinger, Y., \& Turner, L. (1998). Asian and Western cultural differences: The new challenge for tourism marketplaces. Journal of International Hospitality, Leisure \& Tourism Management, 1(3), 21-35. https://doi.org/10.1300/J268v01n03_03

Reisinger, Y., \& Turner, L. (2002). Cultural differences between Asian tourist markets and Australian hosts: Part 2. Journal of Travel Research, 40(4), 295-315. https://doi. org/10.1177/0047287502040003008

Ryu, K., \& Lee, J. S. (2017). Examination of restaurant quality, relationship benefits, and customer reciprocity from the perspective of relationship marketing investments. Journal of Hospitality \& Tourism Research, 41(1), 66-92. https://doi.org/10.1177 /1096348013515919 
Sadeghi, M., Zandieh, D., Mohammadi, M., Yaghoubibijarboneh, B., \& Vosta, S. N. (2017). Investigating the impact of service climate on intention to revisit a hotel: The mediating role of perceived service quality and relationship quality. International Journal of Management Science and Engineering Management, 12(1), 12-20. https:// doi.org/10.1080/17509653.2015.1113395

Santouridis, I., \& Veraki, A. (2017). Customer relationship management and customer satisfaction: The mediating role of relationship quality. Total Quality Management \& Business Excellence, 28(9-10), 1122-1133. https://doi.org/10.1080/14783363.201 7.1303889

Saunders, M., Lewis, P., \& Thornhill, A. (2012). Research methods for business students (6th ed.). Pearson.

Seo, Y. (2012). Cultural impact on customer satisfaction and service quality evaluation in hotels. UNLV Theses, Dissertations, Professional Papers, and Captones, 1370. https://digitalscholarship.unlv.edu/thesesdissertations/1370

Singh, R., \& Khan, I. A. (2012). An approach to increase customer retention and loyalty in B2C world. International Journal of Scientific and Research Publications, $2(6), 1-5$.

Skarmeas, D., Zeriti, A., \& Baltas, G. (2016). Relationship value: Drivers and outcomes in international marketing channels. Journal of International Marketing, 24(1), 22-40. https://doi.org/10.1509/jim.15.0065

Skogland, I., \& Siguaw, J. A. (2004). Are your satisfied customers loyal? Cornell Hotel and Restaurant Administration Quarterly, 45(3), 221-234. https://doi.org/10.1177 /0010880404265231

Smith, A. K., Bolton, R. N., \& Wagner, J. (1999). A model of customer satisfaction with service encounters involving failure and recovery. Journal of Marketing Research, 36(3), 356-372. https://doi.org/10.1177/002224379903600305

Soldatenko, D., \& Backer, E. (2019). A content analysis of cross-cultural motivational studies in tourism relating to nationalities. Journal of Hospitality and Tourism Management, 38, 122-139. https://doi.org/10.1016/j.jhtm.2018.12.004

Solnet, D., \& Kandampully, J. (2008). How some service firms have become part of "service excellence" folklore: An exploratory study. Managing Service Quality: An International Journal, 18(2), 179-193. https://doi.org/10.1108/09604520810859229

Sota, S., Chaudhry, H., \& Srivastava, M. K. (2020). Customer relationship management research in hospitality industry: A review and classification. Journal of Hospitality Marketing \& Management, 29(1), 39-64. https://doi.org/10.1080/19368623.2019.15 95255

Srihadi, T. F., \& Setiawan, D. (2015). The influence of different level of service characteristics and personal involvement towards consumer relational response behaviors. Procedia-Social and Behavioral Sciences, 210, 378-387. https://doi.org/10.1016/j. sbspro.2015.11.385

Stefano, N. M., Filho, N. C., Barichello, R., \& Sohn, A. P. (2015). A fuzzy SERVQUAL based method for evaluated of service quality in the hotel industry. Procedia CIRP, Seventh Industrial Product-Service Systems Conference, 30, 433-438. https://doi. org/10.1016/j.procir.2015.02.140

Su, L., Swanson, S. R., \& Chen, X. (2016). The effects of perceived service quality on repurchase intentions and subjective well-being of Chinese tourists: The mediating role of relationship quality. Tourism Management, 52, 82-95. https://doi.org/10.1016/j. tourman.2015.06.012 
Suhartanto, D. (2011). Hotel brand of origin: Do guests perceive service differences. Journal of Tourism, Hospitality \& Culinary Arts, 3(3), 1-24.

Sukhragchaa, A., \& Oh, H.-C. (2018). A study of service quality and customer satisfaction of upscale hotels in Ulaanbaatar, Mongolia. Korea Tourism Leisure Association Tourism Leisure Research Tourism Leisure Research, 30(2), 173-191.

Tsoukatos, E., \& Rand, G. K. (2006). Path analysis of perceived service quality, satisfaction and loyalty in Greek insurance. Managing Service Quality: An International Journal, 16(5), 501-519. https://doi.org/10.1108/09604520610686746

U.N. World Tourism Organization. (2019). International tourism highlights 2019 edition. https://www.e-unwto.org/doi/pdf/10.18111/9789284421152

U.N. World Tourism Organization. (2020, December). Impact assessment of the Covid19 outbreak on international tourism. https://www.unwto.org/impact-assessment-ofthe-covid-19-outbreak-on-international-tourism

Wang, C., \& Wu, L. (2012). Customer loyalty and the role of relationship length. Managing Service Quality: An International Journal, 22(1), 58-74. https://doi.org $/ 10.1108 / 09604521211198119$

Weber, K., Sparks, B., \& Hsu, C. H. C. (2017). Moving beyond the Western versus Asian culture distinction: An investigation of acculturation effects. International Journal of Contemporary Hospitality Management, 29(6), 1703-1723. https://doi.org/10.1108/ IJCHM-12-2015-0679

Wilkins, H., Merrilees, B., \& Herington, C. (2009). The determinants of loyalty in hotels. Journal of Hospitality Marke.

Williams, P., Soutar, G., Ashill, N. J., \& Naumann, E. (2017). Value drivers and adventure tourism: A comparative analysis of Japanese and Western consumers. Journal of Service Theory and Practice, 27(1), 102-122. https://doi.org/10.1108/JSTP-052015-0116

World Economic Forum. (2020). Asia Pacific. https://reports.weforum.org/travel-andtourism-competitiveness-report-2019/regional-profiles/asia/?doing_wp_cron=15888 30063.1420440673828125000000

World Health Organization. (2020). \#HEALTHYATHOME. https://www.who.int/campaigns/connecting-the-world-to-combat-coronavirus/healthyathome

World Travel \& Tourism Council. (n.d.). The World Travel \& Tourism Council (WTTC) represents the travel \& tourism sector globally. https://wttc.org/en-us/

Wu, S. I., \& Lu, C. L. (2012). The relationship between CRM, RM, and business performance: A study of the hotel industry in Taiwan. International Journal of Hospitality Management, 31(1), 276-285. https://doi.org/10.1016/j.ijhm.2011.06.012

\section{Submitted January 17, 2020 \\ Accepted January 15, 2021 \\ Refereed Anonymously}

Kim-Shyan Fam (Ph.D., University of Newcastle, Australia), Chair Professor of Marketing at Harbin University of Commerce, School of Management, Harbin City, China, kimfam88@gmail.com. His primary research theme is the influence of aspects of culture on the inter-relationships between advertisers and consumers. Primarily he is interested in why and how some elements of culture influence the theory and practice of marketing in a particular Asian market. 
Boon Liat Cheng is an Associate Professor at the Sunway University, Malaysia. He has more than fifteen years of work experience in the tertiary institutions in Malaysia. He is giving lectures on various subjects in marketing and management at both undergraduate and postgraduate levels. His research interests are in the fields of services marketing, customer relationship management, consumer behaviour, entrepreneurship and marketing management.

Tat-Huei Cham is an Associate Professor at UCSI Graduate Business School, UCSI University, Malaysia. His research interests focus on marketing, medical tourism, tourism and hospitality marketing, consumer behaviour, service industry strategy and operations, and e-commerce. He also actively involved as the members of the editorial review board for several international journals. Dr Cham is the corresponding author and he can be contacted at: jaysoncham@gmail.com.

Mandy Tan Chia Yi is graduated first-class from Sunway University with a Bachelor of Science (Hons) in Business Studies majoring in Management and Marketing. She is currently working in a world-leading insurance company as a Management Associate. Her research interests are in the fields of marketing and consumer behaviour.

Dr Hiram Ting is an Associate Professor at the Faculty of Hospitality and Tourism Management, UCSI University, Malaysia and Professorial Chair at the Polytechnic University of the Philippines. He holds a $\mathrm{PhD}$ in marketing and is involved in various behavioural research. He is also actively engaged in industry and community-based projects. 